\title{
Analysis of the peri-implant microbiota in 90 dental implants and its relationship to crevicular fluid volume
}

\author{
Javier Ata-Ali ${ }^{1}$, Antonio Juan Flichy-Fernández ${ }^{2}$, Teresa Alegre-Domingo ${ }^{2}$, María Eugenia Candel-Marti ${ }^{3}$, \\ David Peñarrocha Oltra ${ }^{3}$, José Francisco Balaguer-Martinez ${ }^{4}$, María Peñarrocha ${ }^{4}$
}

\author{
${ }^{1}$ DDS. Master in Oral Medicine and Surgery. Master in Oral Surgery and Implantology. Valencia University Medical and Dental \\ School \\ ${ }^{2}$ DDS. Master in Oral Surgery and Implantology. Valencia University Medical and Dental School \\ ${ }^{3}$ DDS. Resident of the Master in Oral Surgery and Implantology. Valencia University Medical and Dental School \\ ${ }^{4}$ Associate Professor of Oral Surgery. Valencia University Medical and Dental School. Valencia (Spain)
}

Correspondence:

Cirugía Bucal,

Clínicas Odontológicas,

Gascó Oliag 1

46021 - Valencia (Spain)

Maria.Penarrocha@uv.es

Received: 01/08/2010

Accepted: $14 / 11 / 2010$
Ata-Ali J, Flichy-Fernández AJ, Alegre-Domingo T, Candel-Marti ME, Peñarrocha D, Balaguer-Martinez JF, Peñarrocha MA. Analysis of the peri-implant microbiota in 90 dental implants and its relationship to crevicular fluid volume. Med Oral Patol Oral Cir Bucal. 2011 Nov 1;16 (7):e944-7.

http://www.medicinaoral.com/medoralfree01/v16i7/medoralv16i7p944.pdf

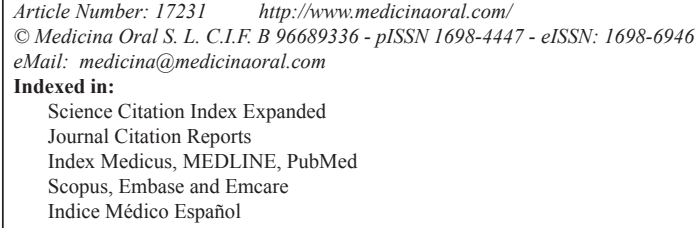

\begin{abstract}
Objective: To evaluate the presence within the peri-implant sulcus of Tannerela forsythia (Tf), Porphyromonas gingivales $(\mathrm{Pg})$, Treponema denticola $(\mathrm{Td})$ and Aggregatibacter actinomycetemcomitans (Aa), and relate these bacteria to the peri-implant crevicular fluid volume (PICFV).

Material and Method: A prospective and cross-sectional clinical case series study was made. For the measurement of crevicular fluid, use was made of the Periotron ${ }^{\circledR} 8000$ (Proflow Incorporated. New York, USA), measuring the volume in Periotron units (PU). For the detection of periodontopathogenic bacteria we used the IAI-PadoTest 4.5 (IAI Inc., IAI Institute, Zuchwil, Switzerland) - a system for the detection of Tf, Pg, Td and Aa based on the use of RNA arrays.

Results: We included 34 patients (19 females and 15 males) with a mean age of 56.4 years. Of these subjects, $30.8 \%$ were smokers and 69.2\% non-smokers. Out of a total series of 213 implants, we analyzed the crevicular fluid and microbiota in 90 implants. A total of $16.5 \%$ of the implants presented mucositis, while $83.5 \%$ were in healthy periimplant conditions. The microbiological study revealed the presence of $\mathrm{Tf}$ in $17.1 \%$ of the implants, $\mathrm{Pg}$ in $9.3 \%$, Td in $13.6 \%$, in Aa in none of the implants. The mean Periotron reading was 93.4 PU (range 12-198 PU). A statistically significant $(\mathrm{p}<0.05)$ relationship was observed between PICFV and the total percentage bacteria (Tf, Pg and $\mathrm{Td}$ ) - with a strong association between the Td levels and smoking $(\mathrm{p}<0.01)$. In the implants with mucositis, the concentration of $\mathrm{Pg}$ and $\mathrm{Td}$ was greater.

Conclusions: In the implants studied, the subgingival peri-implant microbiota was characterized by low levels of $\mathrm{Pg}$, Tf, Td, and none of the patients proved positive for Aa. These bacteria showed a positive correlation to crevicular fluid volume, and a statistically significant relationship was observed between Td and smoking.
\end{abstract}

Key words: Tannerela forsythia, Porphyromonas gingivales, Treponema denticola, Aggregatibacter actinomycetemcomitans, peri-implant microbiota, crevicular fluid volume, smoking. 


\section{Introduction}

The microbiota that colonizes dental implants in healthy totally edentulous patients is very similar to that colonizing the teeth of periodontically healthy individuals (1). The main pathogens implicated in peri-implant diseases are gramnegative anaerobic bacteria, with an increased percentage presence of mobile and fusiform bacilli and spirochetes (2).

Recently, Aas et al. (3) identified over 700 species occupying specific ecological niches in the oral cavity. However, the bacterial species Tf, Pg and Td have been the most aggressive pathogens, representing the "red complex" in the Socransky classification of the subgingival microbiota, and being strongly related to bone destruction $(1,4)$. While Aa has not been included in the red complex, it has been found to be present in the microbiota associated to peri-implantitis $(5,6)$.

Crevicular fluid is a potent plasma exudate, and in certain pathological situations (gingivitis, periodontitis, peri-implantitis) its secretion increases with respect to healthy conditions $(7,8)$. Stewart et al. (9) consider that peri-implant crevicular fluid measurement should be viewed as an objective indicator of the degree of periimplant tissue inflammation.

The present study was designed to evaluate the presence in crevicular fluid of Tf, Pg, Td and Aa in totally edentulous patients subjected to dental implant rehabilitation, and to relate these bacteria to the PICFV.

\section{Material and Method}

Selection of the patients and implants

A prospective and cross-sectional clinical case series study was made between January 2009 and July 2009 in an Oral Surgery Unit of a University Clinic. A total of 251 dental implants were placed in 40 patients. Regarding the inclusion criteria, we selected totally edentulous patients with at least one fully implant-restored dental arch, subjected to maintenance every 6 months. We in turn excluded those patients subjected to any type of local or systemic decontamination treatment of the oral cavity in the last three months (e.g., antibiotics or rinses); patients with uncontrolled peri-implant disease (suppuration or important bleeding after probing, with a pocket depth of over $5 \mathrm{~mm}$ ); patients with implants in which the rough implant surface was exposed; patients with systemic diseases or medicated with drugs capable of altering gingival health in any way; and pregnant or nursing women. Sample selection was software randomized.

One implant per implant-restored quadrant was selected, peri-implant crevicular fluid measurements were made, and microbiological samples were collected.

All patients gave written informed consent before sample collection, in accordance with the principles of the Declaration of Helsinki, and with authorization from the Ethics Committee of the center.
Collection of microbiological samples

The supragingival plaque was removed with a curette or cotton swab, without penetrating the gingival sulcus. Relative isolation was ensured with cotton rolls. The sampling zone was pressure air-dried. Sterile paper tips (Johnson \& Johnson, Medical Inc., Arlington, TX, USA) were inserted to the bottom of the peri-implant sulcus during 10 seconds. Each paper tip was then placed in a tube, which was shaken to uniformly distribute its liquid contents (guanidine thiocyanate $4 \mathrm{M}$ and 2-mercaptoethanol), impregnating the paper tip. For the microbiological analysis, the samples were shipped to IAI Inc., where evaluations were made of Pg, Aa, Tf and $\mathrm{Td}$, using the IAI-PadoTest $4.5^{\circledR}$ (IAI Inc., IAI Institute, Zuchwill, Switzerland). To this effect, the samples were mounted in nylon membranes and hybridized with specific P32 arrays directed against the sRNA ribosomal subunit (ssrRNAs) of the four above mentioned periodontal bacterial species.

Measurement of crevicular fluid volume

After calibrating the Periotron ${ }^{\circledR} 8000$ (Proflow Incorporated. New York, USA), a crevicular fluid sample of the dental implants was collected with sterile paper strips (Periopaper Strip ${ }^{\circledR}$. Proflow Incorporated. New York, USA) - processing one sample per implant-restored quadrant.

The technique used was as follows: a) drying of the mouth with aspiration; b) isolation of the zone with cotton rolls; c) gentle drying of the zone; d) crevicular fluid sampling by placing the sterile paper tips in the sulcus between the implant and gums, and keeping this position for 30 seconds; and e) placement between the sensors of the Periotron ${ }^{\circledR} 8000$, to record the amount of crevicular fluid obtained in Periotron units previously calibrated following the indications of the manufacturer).

Statistical analysis

The SPSS version 15.0 statistical package for Microsoft Windows (SPSS Inc., Chicago, IL, USA) was used for the statistical analysis of the results, based on the Pearson and Spearman correlation coefficients, and accepting statistical significance for $\mathrm{p}<0.05$.

\section{Results}

Six patients were excluded from the study: two due to antibiotic use, two due to the use of oral rinses, and another two who presented an incomplete protocol. A total of 34 patients (19 females and 15 males) were thus finally included. Twenty-three patients presented rehabilitation of a single maxilla with dental implants, while 11 presented implant-based restoration of both maxillas. The mean age was 56.4 years (range 46-85). Fourteen of the patients wore fixed prostheses, 11 involving overdentures with Locator ${ }^{\circledR}$ (Zest Anchors, Escondido, CA, USA), and 9 overdentures with bars. On the other hand, 
Table 1. Statistical correlations among bacteria, smoking and peri-implant crevicular fluid volume.

\begin{tabular}{|c|c|c|}
\hline & Statistical test & P-value \\
\hline Bacteria and PICFV & $\mathrm{R}_{2=0.187}$ & $<0.05$ \\
\hline Bacteria and smoking & $\mathrm{R}_{1=0.271}$ & $<0.01$ \\
\hline
\end{tabular}

$\mathrm{R}_{1}$ : Pearson correlation; $\mathrm{R}_{2}$ : Spearman correlation; $\mathrm{p}$ : statistical significance; PICFV: peri-implant crevicular fluid volume.

Table 2. Presence of bacteria significantly correlated to patients with mucositis.

\begin{tabular}{|c|c|}
\hline $\operatorname{Pg} \uparrow$ & $\mathrm{p}<0.01$ \\
\hline $\operatorname{Td} \mathrm{t}$ & $\mathrm{p}<0.05$ \\
\hline \multicolumn{2}{|c|}{$\begin{array}{l}\text { I Porphyromonas } \\
\text { gingivales } \\
\text { € Treponema denticola }\end{array}$} \\
\hline
\end{tabular}

$30.8 \%$ of the subjects were smokers while $69.2 \%$ were non-smokers. A total of 213 dental implants were placed, with analysis in the present study of 90 implants. A total of $16.5 \%$ of the implants presented mucositis, while $83.5 \%$ were in healthy peri-implant conditions. The microbiological study revealed the presence of $\mathrm{Tf}$ in $17.1 \%$ of the implants, $\mathrm{Pg}$ in $9.3 \%$, Td in $13.6 \%$, in Aa in none of the implants. The mean Periotron reading was 93.4 PU (range 12-198 PU). Spearman correlation revealed a statistically significant correlation between total percentage bacteria (Tf, Pg and Td) and crevicular fluid volume (Table 1). In the presence of mucositis, the concentration of Pg and Td was found to be significantly greater (Pg: $\mathrm{p}<0.01$ and Td: $\mathrm{p}<0.05$ ) (Table 2).

In turn, Pearson correlation to evaluate the association between smoking and the presence of these bacteria showed smokers to present a significantly greater amount of Td, with no observed influence upon any of the other bacterial species.

\section{Discussion}

The IAI-PadoTest $4.5^{\circledR}$ is a system designed to detect periodontopathogenic bacteria based on the use of RNA arrays. Some studies have used this technique for the detection and quantification of bacteria in the diagnosis and treatment of the periodontal and peri-implant diseases (10-15). Cosgarea et al. (15), using two microbiological tests, the Pado Test and real-time polymerase chain reaction (RT-PCR), observed a high percentage coincidence for $\mathrm{Pg}$, Tf and $\mathrm{Td}$ with both tests.

In our study, $17.1 \%$ of the implants revealed the presen- ce of Tf, while $9.3 \%$ yielded $\mathrm{Pg}$ and $13.6 \%$ showed the presence of Td. In no case was Aa observed. Other authors have published similar results. Salvi et al. (16), in a study of 17 healthy implants, reported the presence of Pg in $13.5 \%$ of the implants, $\mathrm{Tf}$ in $11.8 \%$, Td in $5.4 \%$ Td, and Aa in $2.7 \%$. Renvert et al. (17), in a study of 55 healthy subjects and 31 patients with peri-implantitis, recorded the presence of Td in $13.2 \%$ of the healthy implants, with Pg in $7.9 \%$, Tf in $5.3 \%$, and $\mathrm{Aa}$ in $2.7 \%$.

Other authors $(18,19)$ in turn have observed a significant increase in the risk of bone loss when $\mathrm{Aa}$ is present at levels of 104, and Pg at levels of 105. In the present study we did not observe Aa, and the Pg levels were under $105(44,000)$.

We observed a positive correlation between crevicular fluid volume and the red complex bacteria, in coincidence with the data published by Teles et al. (20).

Smoking as a risk factor for peri-implant disease influences the subgingival microbiota, as well as PICFV and its composition (20). Some bacterial species have been more closely correlated to smoking, such as Tf, which revealed a significantly greater presence in active smokers (21). Delima et al. (22) reported a significant reduction in the presence of Td after one year of smoking cessation. This agrees with our own study, in which a strong association was recorded between the $\mathrm{Td}$ levels and smoking $(\mathrm{p}<0.001)$.

The measurement of PICFV and the analysis of the peri-implant microbiota could predict the change from healthy conditions towards peri-implant disease. Accepting the limitations of this study, it can be concluded that the subgingival peri-implant microbiota in our series presents low levels of $\mathrm{Pg}$, Tf and $\mathrm{Td}$, and moreover none of our patients presented Aa. These bacteria showed a positive correlation to crevicular fluid volume, with a statistically significant relationship between $\mathrm{Td}$ and smoking. Lastly, in the presence of mucositis, the concentration of Pg and Td is seen to increase.

\section{References}

References with links to Crossref - DOI

1. Socransky SS, Haffajee AD. Periodontal microbial ecology. Periodontol 2000. 2005;38:135-87.

2. Bascones Martínez A, Aguirre Urízar JM, Bermejo Fenoll A, Blanco Carrión A, Gay-Escoda C, González-Moles MA, et al. Consensus statement on antimicrobial treatment of odontogenic bacterial infections. Med Oral Patol Oral Cir Bucal. 2004;9:369-76; 363-9.

3. Aas JA, Paster BJ, Stokes LN, Olsen I, Dewhirst FE. Defining the normal bacterial flora of the oral cavity. J Clin Microbiol. 2005;43:5721-32.

4. Socransky SS, Haffajee AD, Cugini MA, Smith C, Kent RL Jr. Microbial complexes in subgingival plaque. J Clin Periodontol. 1998;25:134-44.

5. Van Winkelhoff AJ, Goené RJ, Benschop C, Folmer T. Early colonization of dental implants by putative periodontal pathogens in partially edentulous patients. Clin Oral Implants Res. 2000;11:511-20.

6. Hultin M, Gustafsson A, Hallström H, Johansson LA, Ekfeldt A, Klinge B. Microbiological findings and host response in patients with peri-implantitis. Clin Oral Implants Res. 2002;13:349-58.

7. Martínez PM, Torres AR, Ortiz de Lejarazu R, Montoya A, Mar- 
tín JF, Eiros JM. Human immunodeficiency virus antibody testing by enzyme-linked fluorescent and western blot assays using serum, gingival-crevicular transudate, and urine samples. J Clin Microbiol. 1999;37:1100-6.

8. Ericsson I, Berglundh T, Marinello C, Liljenberg B, Lindhe J. Long-standing plaque and gingivitis at implants and teeth in the dog. Clin Oral Implants Res. 1992;3:99-103.

9. Stewart JE, Christenson PD, Maeder LA, Palmer MA. Reliability of filter-strip sampling of gingival crevicular fluid for volume determination using the Periotron. J Periodontal Res. 1993;28:227-30.

10. Luterbacher S, Mayfield L, Brägger U, Lang NP. Diagnostic characteristics of clinical and microbiological tests for monitoring periodontal and peri-implant mucosal tissue conditions during supportive periodontal therapy (SPT). Clin Oral Implants Res. 2000;11:521-9.

11. Kamma JJ, Baehni PC. Five-year maintenance follow-up of earlyonset periodontitis patients. J Clin Periodontol. 2003;30:562-72.

12. Mombelli A, Brochut P, Plagnat D, Casagni F, Giannopoulou C. Enamel matrix proteins and systemic antibiotics as adjuncts to nonsurgical periodontal treatment: clinical effects. J Clin Periodontol. 2005;32:225-30.

13. Brochut PF, Marin I, Baehni P, Mombelli A. Predictive value of clinical and microbiological parameters for the treatment outcome of scaling and root planing. J Clin Periodontol. 2005;32:695-701.

14. Eguchi T, Koshy G, Umeda M, Iwanami T, Suga J, Nomura Y, et al. Microbial changes in patients with acute periodontal abscess after treatment detected by PadoTest. Oral Dis. 2008;14:180-4.

15. Cosgarea R, Bäumer A, Pretzl B, Zehaczek S, Kim TS. Comparison of two different microbiological test kits for detection of periodontal pathogens. Acta Odontol Scand. 2010;68:115-21.

16. Salvi GE, Fürst MM, Lang NP, Persson GR. One-year bacterial colonization patterns of Staphylococcus aureus and other bacteria at implants and adjacent teeth. Clin Oral Implants Res. 2008;19:242-8. 17. Renvert S, Roos-Jansåker AM, Lindahl C, Renvert H, Rutger Persson G. Infection at titanium implants with or without a clinical diagnosis of inflammation. Clin Oral Implants Res. 2007;18:509-16. 18. Haffajee AD, Dibart S, Kent RL Jr, Socransky SS. Factors associated with different responses to periodontal therapy. J Clin Periodontol. 1995;22:628-36.

19. Haffajee AD, Socransky SS, Dibart S, Kent RL Jr. Response to periodontal therapy in patients with high or low levels of $\mathrm{P}$. gingivalis, P. intermedia, P. nigrescens and B. forsythus. J Clin Periodontol. 1996;23:336-45.

20. Teles RP, Gursky LC, Faveri M, Rosa EA, Teles FR, Feres M, et al. Relationships between subgingival microbiota and GCF biomarkers in generalized aggressive periodontitis. J Clin Periodontol. 2010;37:313-23.

21. Chukhlovin AB, Solovyova AM, Matelo SK, Kobiyasova IV, Morosova EB, Hokhlacheva AV, et al. Bacterial markers of periodontal diseases and their practical significance in dentistry. Bull Exp Biol Med. 2007;144:546-50.

22. Delima SL, McBride RK, Preshaw PM, Heasman PA, Kumar PS. Response of subgingival bacteria to smoking cessation. J Clin Microbiol. 2010;48:2344-9.

\section{Acknowledgements}

The authors are grateful to IAI, Zuchwil, Switzerland, for the microbiological analyses, and particularly to Dr. Ignacio Bolivar, for processing of the samples. 